Original Article

\title{
VALIDATED SPECTROPHOTOMETRIC METHOD TO DETERMINE VARDENAFIL AND SILDENAFIL IN PHARMACEUTICAL FORMS USING POTASSIUM IODIDE AND POTASSIUM IODATE
}

\author{
AMIR ALHAJ SAKUR, SHAZA AFFAS \\ Analytical and Food Chemistry Department, Faculty of Pharmacy, University of Aleppo, Syria \\ Email: shazaaffas@gmail.com
}

Received: 08 Jun 2017 Revised and Accepted: 21 Sep 2017

\begin{abstract}
Objective: To develop and validate simple, sensitive, precise and free of organic solvents method for the determination of sildenafil (SIL) and vardenafil (VAR) in bulk and pharmaceutical formulation.

Methods: The method is based on the reaction of studied drugs with a mixture of potassium iodide and potassium iodate in an aqueous medium at $\left(25 \pm 2{ }^{\circ} \mathrm{C}\right)$ to form yellow coloured triiodide ions $\left(\mathrm{I}_{3}{ }^{-}\right)$within $45 \mathrm{~min}$. The reaction is followed spectrophotometrically by measuring the absorbance at 288, $351 \mathrm{~nm}$ and $285,351 \mathrm{~nm}$ for sildenafil and vardenafil respectively.

Results: The effects of analytical parameters on the reported systems were investigated. Beer's law of SIL was obeyed in the range of (0.4-12) $\mu \mathrm{g} \mathrm{ml-}$ ${ }^{1}$ and $(0.6-16) \mu \mathrm{g} \mathrm{m}^{-1}$. Molar absorptivity was found to be $\left(67.659 \times 10^{3}\right) \mathrm{lmol} / \mathrm{cm}$ and $\left(37.955 \times 10^{3}\right) \mathrm{lmol} / \mathrm{cm}$ at $288 \mathrm{~nm}, 351 \mathrm{~nm}$ respectively. Beer's law of VAR was obeyed in the range of $(0.2-13) \mu \mathrm{g} / \mathrm{ml}$ and $(0.5-40) \mu \mathrm{g} / \mathrm{ml}$. Moreover, molar absorptivity's were found to be $\left(68.719 \times 10^{3}\right) \mathrm{l} \mathrm{mol}{ }^{-1} \mathrm{~cm}^{-}$ ${ }^{1}$ and $\left(26.691 \times 10^{3}\right) \mathrm{l} \mathrm{mol}^{-1} \mathrm{~cm}^{-1}$ at $285 \mathrm{~nm}, 351 \mathrm{~nm}$ respectively.
\end{abstract}

Conclusion: The proposed method has been applied to determine the components in dosage forms with an average recovery of $98.15 \%$ to $103.45 \%$ and the results have been found in good agreement with those results obtained by the reference methods.

Keywords: Sildenafil citrate, Vardenafil hydrochloride, Spectrophotometry, Potassium iodide, Potassium Iodate, Triiodide ion

(C) 2017 The Authors. Published by Innovare Academic Sciences Pvt Ltd. This is an open-access article under the CC BY license (http://creativecommons.org/licenses/by/4.0/) DOI: http://dx.doi.org/10.22159/ijpps.2017v9i11.20578

\section{INTRODUCTION}

Erectile dysfunction (ED) is one of the most common chronic diseases affecting men and its prevalence increases with aging. It is also the most frequently diagnosed sexual dysfunction in the older male population. Treatment of erectile dysfunction is based on phosphodiesterase type 5 (PDE-5) inhibitors including sildenafil (SIL), and vardenafil (VAR). PDE-5 inhibitors have high efficacy and safety rates, even in difficult-to-treat populations such as patients with diabetes mellitus [1]. Sildenafil citrate was the first drug approved for the treatment of ED in 1998. The United States food and drug administration (FDA) approved tadalafil and vardenafil hydrochloride in 2003 [2].

There are several studies in medical literature reporting the determination of sildenafil citrate in pharmaceuticals, plasma samples, herbal drugs or dietary supplements using liquid chromatography method [1-7], electroanalytical methods [8, 9]gas chromatography [10], Thin layer chromatography [11], capillary electrophoresis [12] and capillary chromatography [1315]. Many spectrophotometric Methods have also been reported [16-22].

As same as, determination of VAR in bulk, tablet dosage forms, and biological fluids were analyzed using different analytical systems, including HPLC [3, 23-25], capillary electrophoresis [26] capillary chromatography [27] LC-MS [28], and spectrophotometric methods $[29,30]$. In the previous studies, the spectrophotometric determination of SIL and VAR depend on UV spectrophotometric method, oxidation of the drug and complex formation. Most of these methods demand organic solvents or organic reagents, unlike the proposed method.

The aim of the present study was to report a new, simple, and environment-friendly method to determination SIL and VAR as raw materials and in pharmaceutical preparations.

\section{MATERIALS AND METHODS}

\section{Apparatus}

Uv-visible spectrophotometer (JASCO, model V650, Japan) with 1.00 $\mathrm{cm}$ quartz cells. Ultrasonic processor (Powersonic, model 405, Korea) was used to sonicate the sample solutions. Adjustable micropipettes covering a volume range from 2 to $5000 \mu \mathrm{l}$ (ISO-LAB, Germany), used for the preparation of the experimental solutions. Analytical balance (Sartorius, model 2474, Germany). pH meter (CRISON, GLp21/Eu, Spain).

\section{Chemicals and reagents}

Pharmaceutical grade sildenafil (99\%) and vardenafil (99.5\%) were received from XUHUANG, CHINA. Potassium iodate and potassium iodide (Panreac, Germany). All reagents and solvents were of analytical grade. Stock standard solution $\left(1 \mathrm{mg} \mathrm{ml}^{-1}\right)$ of SIL and VAR was prepared by dissolving $25 \mathrm{mg}$ from each of SIL and VAR in double distilled water and diluting to $25 \mathrm{ml}$ with double distilled water. $0.15 \mathrm{M}$ of potassium iodate and $0.2 \mathrm{M}$ of potassium iodide solutions were prepared by dissolving the accurately weighed amount of the pure solid in double distilled water. All other chemicals and reagents were of analytical grade and all solutions were prepared with double distilled water. All solutions are stable for a period of $2 \mathrm{~d}$ when stored at $\left(4^{\circ} \mathrm{C}\right)$.

\section{General procedure}

Increasing volumes of SIL or VAR working standard solution were transferred into series of $10 \mathrm{ml}$ volumetric flasks that contain $2.5 \mathrm{ml}$ of $\mathrm{KI}(0.2 \mathrm{M})$ and $1 \mathrm{ml}$ of $\mathrm{KIO}_{3}(0.15 \mathrm{M})$ for SIL and $3 \mathrm{ml}$ of $\mathrm{KI}(0.2 \mathrm{M})$ and $1.0 \mathrm{ml}$ of KIO3 $(0.15 \mathrm{M})$ for VAR. The volume was made up to the mark with distilled water and the absorbance was measured after $45 \mathrm{~min}$ at 288, $351 \mathrm{~nm}$ and 285, $351 \mathrm{~nm}$ against a similar reagent blank for SIL and VAR respectively. The standard calibration plot was prepared to calculate the amount of the analyzed drug in bulk samples. All measurements were carried out at room temperature $\left(25 \pm 2^{\circ} \mathrm{C}\right)$. 


\section{Procedure for pharmaceutical formulations}

Twenty individual tablets were weighed and pulverized carefully. An accurately weighed amount of the powder equivalent to $50 \mathrm{mg}$ of SIL or VAR was transferred into $50 \mathrm{ml}$ volumetric flask and dissolve in $50 \mathrm{ml}$ of water. The content of the flask was sonicated for $30 \mathrm{~min}$ then diluted to the volume with water. A portion of this solution was centrifuged for $15 \mathrm{~min}$ at $5000 \mathrm{rpm}$ then a suitable volume of the supernatant was transferred into $10 \mathrm{ml}$ volumetric flask, and the procedure was continued to use for the analysis of SIL/VAR by the spectrophotometric method after $45 \mathrm{~min}$.

\section{RESULTS AND DISCUSSION}

\section{Absorption spectra}

Iodide ions convert to free iodine in an acidic medium of VAR or SIL solution, the acidity comes from $\mathrm{HCl}$ or $\mathrm{H}_{3} \mathrm{Cit}$, then free iodine reacts with a surplus of iodide ions to form yellow complex from triiodide (I $\left.{ }^{3-}\right)$ (fig. 2, 3) [31].

\section{$\mathrm{IO}_{3}{ }^{-}+5 \mathrm{I}^{-}+6 \mathrm{H}^{+} \rightarrow 2 \mathrm{I}_{3}{ }^{-}+3 \mathrm{H}_{2} \mathrm{O}$}

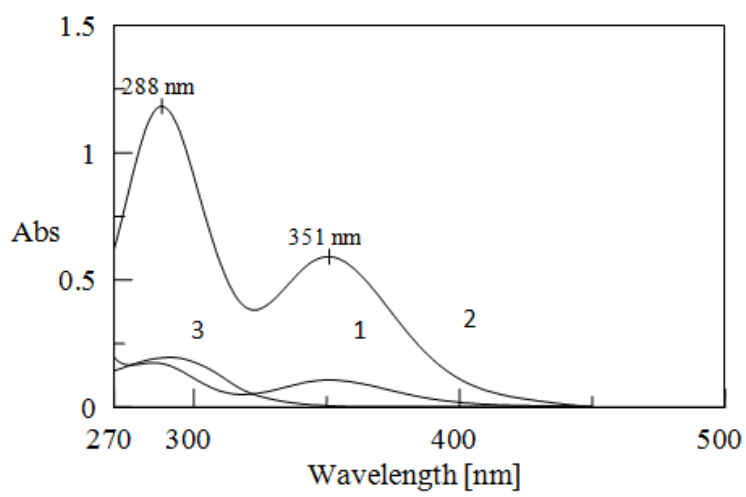

Fig. 1: Absorption spectra of (1) reagent blank against distilled water, (2) SIL $\left(12.0 \mu \mathrm{g} \mathrm{ml}^{-1}\right)+2.5 \mathrm{ml}$ of $0.20 \mathrm{M} \mathrm{KI}+1.0 \mathrm{ml}$ of $0.15 \mathrm{M}$ $\mathrm{KIO}_{3}$ against reagent, Blank, (3) SIL against distilled water

\section{Optimization of reaction conditions}

The optimum conditions for the development of method were established by varying one parameter at a time and keeping the others fixed and observing the effect produced on the absorbance of the coloured products.

A volume of $2.5 \mathrm{ml}$ of $0.2 \mathrm{M} \mathrm{KI}, 1.0 \mathrm{ml}$ of $0.15 \mathrm{M} \mathrm{KIO}_{3}$ and $3.0 \mathrm{ml}$ of $0.20 \mathrm{M} \mathrm{KI}, 1.0 \mathrm{ml}$ of $0.15 \mathrm{M} \mathrm{KIO}_{3}$ were found to be optimum for maximum colour development for determination of SIL and VAR respectively. Since the absorbances were found to be maximal at the mentioned volumes. The laboratory temperature $\left(25 \pm 2{ }^{\circ} \mathrm{C}\right)$, and the time of reaction was $45 \mathrm{~min}$ to obtain the optimum absorbance for all the experiments.

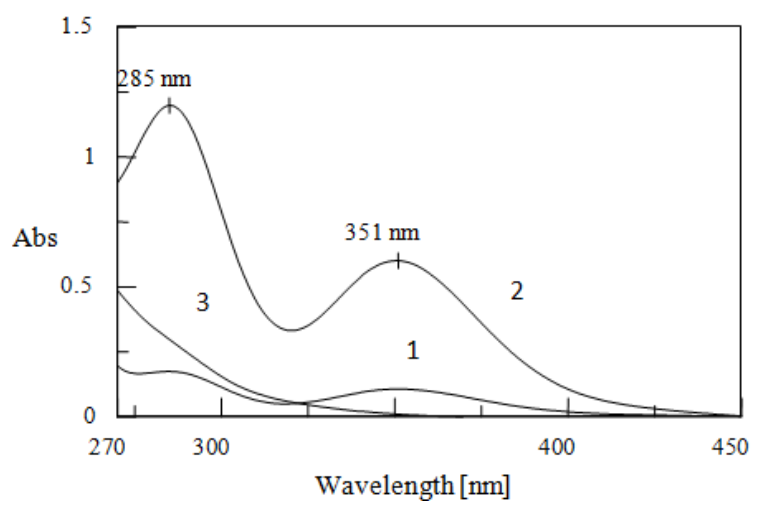

Fig. 2: Absorption spectra of (1) reagent blank against distilled water, (2) VAR (13.0 $\left.\mu \mathrm{g} \mathrm{ml}^{-1}\right)+3 \mathrm{ml}$ of $0.20 \mathrm{M} \mathrm{KI}+1.0 \mathrm{ml}$ of $0.15 \mathrm{M}$ $\mathrm{KIO}_{3}$ against reagent, Blank, (3) VAR against distilled water

\section{Analytical method validation \\ Linearity}

At described experimental conditions for determination of SIL and VAR, standard calibration curves with good linearity were obtained. The molar absorptivities, detection limits, and limits of quantification were calculated. The high molar absorptivities of the resulting coloured product indicate the high sensitivity of the method. Values of some analytical characteristics for proposed procedures were shown in table 1 .

\section{Accuracy and precision}

The accuracy and precision of the proposed procedures were carried out by five determinations at several different concentrations for SIL and VAR. Percentage relative standard deviation (RSD \%) as precision and percentage recovery as an accuracy of the suggested procedures were calculated and showed in table 2. The values of relative standard deviations for different concentrations of drugs determined from the calibration curves. These results of accuracy and precision show that the proposed procedures have good repeatability and reproducibility. The proposed method is selective to the assay of SIL and VAR in the presence of various excipients.

Table 1: Analytical parameters of spectrophotometric methods

\begin{tabular}{lllll}
\hline parameters & SIL & & VAR & \\
\cline { 2 - 5 } & $\mathbf{2 8 8} \mathbf{~ n m}$ & $\mathbf{3 5 1} \mathbf{~ m}$ & $\mathbf{2 8 5} \mathbf{~ n m}$ & $\mathbf{3 5 1} \mathbf{n m}$ \\
\hline Linear rang $\mu \mathrm{g}^{-\mathrm{ml}^{-1}}$ & $0.4-12$ & $0.6-16$ & $0.2-13$ & $0.5-40$ \\
$\varepsilon \mathrm{L} \mathrm{mol}^{-1} \mathrm{~cm}^{-1}$ & $67.659 \times 10^{3}$ & $37.955 \times 10^{3}$ & $68.719 \times 10^{3}$ & $26.691 \times 10^{3}$ \\
Detection limit $\mu$ g. $\mathrm{ml}^{-1}$ & 0.07 & 0.09 & 0.04 & 0.08 \\
Limit of quantification $\mu \mathrm{g} . \mathrm{ml}^{-1}$ & 0.25 & 0.3 & 0.13 & 0.25 \\
Regression equation & $*(\mathrm{~A}=\mathrm{m} \mathrm{C}+\mathrm{b})$ & & $\mathrm{m}=0.109$ & $\mathrm{~m}=0.044$ \\
& $\mathrm{~m}=0.099$ & $\mathrm{~m}=0.052$ & $\mathrm{~b}=0.012$ & $\mathrm{~b}=0.005$ \\
Correlation coefficient & $\mathrm{b}=0.002$ & $\mathrm{~b}=0.011$ & 0.9985 & 0.9994 \\
\hline
\end{tabular}

*With respect to $\mathrm{A}=\mathrm{mC}+\mathrm{b}$, where $\mathrm{C}$ is the concentration $\left(\mu \mathrm{g} . \mathrm{ml}^{-1}\right)$ and $\mathrm{A}$ is the absorbance.

\section{Application to the pharmaceutical dosage forms}

The proposed procedures were applied to determine the studied substances in their pharmaceutical formulations. The results in table 3 indicate the high accuracy and precision. As can be seen from table 3, the proposed method has the advantages of being virtually free from interferences by excipients and common degradation products. The results obtained were compared statistically by the student's t-test (for accuracy) and the variance ratio F-test (for precision) with those obtained by the reference methods $[3,23]$ on samples of the 
same batch (table 3 ). The values of t-and F-tests obtained at 95\% confidence level and four degrees of freedom did not exceed the theoretical tabulated value indicating that no significant difference between the proposed method and references method.

Table 2: Accuracy and precision of the determination of SIL and VAR in bulk powder by the proposed method

\begin{tabular}{|c|c|c|c|c|c|c|}
\hline \multirow{2}{*}{$\begin{array}{l}\text { Drug } \\
\text { SIL }\end{array}$} & \multirow{2}{*}{$\begin{array}{l}\lambda_{\text {max }}, \mathbf{n m} \\
288\end{array}$} & \multicolumn{3}{|l|}{$\mathrm{Mg} / \mathrm{ml}$} & \multirow[t]{2}{*}{$\mathrm{RSD}^{* * *} \%$} & \multirow[t]{2}{*}{ Recovery\% } \\
\hline & & Taken & Found & Found $^{*} \pm S . \mathrm{D}^{* *}$ & & \\
\hline & & 0.4 & 0.403 & $0.403 \pm 0.015$ & 3.69 & 100.80 \\
\hline & & 2 & 2.014 & $2.014 \pm 0.039$ & 1.94 & 100.70 \\
\hline & & 8 & 8.056 & $8.056 \pm 0.113$ & 1.40 & 100.70 \\
\hline & & 12 & 12.130 & $12.130 \pm 0.140$ & 1.15 & 101.08 \\
\hline & 351 & 0.6 & 0.595 & $0.595 \pm 0.025$ & 4.21 & 99.16 \\
\hline & & 4 & 4.067 & $4.067 \pm 0.112$ & 2.75 & 101.67 \\
\hline & & 10 & 10.044 & $10.044 \pm 0.192$ & 1.91 & 100.44 \\
\hline & & 16 & 16.050 & $16.050 \pm 0.250$ & 1.56 & 100.31 \\
\hline \multirow[t]{8}{*}{ VAR } & 285 & 0.2 & 0.207 & $0.207 \pm 0.207$ & 4.40 & 103.45 \\
\hline & & 1 & 1.026 & $1.026 \pm 0.047$ & 4.58 & 102.60 \\
\hline & & 8 & 8.132 & $8.132 \pm 0.130$ & 1.60 & 101.65 \\
\hline & & 13 & 12.950 & $12.950 \pm 0.209$ & 1.61 & 99.615 \\
\hline & 351 & 0.5 & 0.501 & $0.501 \pm 0.021$ & 4.26 & 100.29 \\
\hline & & 4 & 4.092 & $4.092 \pm 0.125$ & 3.05 & 102.30 \\
\hline & & 20 & 19.631 & $19.631 \pm 0.228$ & 1.16 & 98.15 \\
\hline & & 40 & 40.307 & $40.307 \pm 0.363$ & 0.90 & 100.76 \\
\hline
\end{tabular}

*Average of five determinations, ${ }^{* *}$ Standard diviation, ${ }^{* * *}$ Relative standard deviation.

Table 3: Determination of SIL and VAR in their pharmaceutical preparations using the proposed and reference methods

\begin{tabular}{|c|c|c|c|c|c|}
\hline \multirow[t]{3}{*}{ Formula } & \multirow[t]{3}{*}{ Drug } & \multirow{3}{*}{$\begin{array}{l}\text { Claim } \\
\text { (mg/tab) }\end{array}$} & \multicolumn{3}{|c|}{ Found $\% \pm$ SD* } \\
\hline & & & \multicolumn{2}{|c|}{ Proposed method $\lambda_{\max }, \mathrm{nm}$} & \multirow[t]{2}{*}{ Reference method [3] } \\
\hline & & & 288 & 351 & \\
\hline \multirow[t]{10}{*}{ VIGRAVID } & SIL & 25 & $25.14 \pm 1.17$ & $25.06 \pm 1.92$ & $25.19 \pm 0.52$ \\
\hline & & & $\mathrm{t}=1.02$ & $\mathrm{t}=1.35$ & $\mathrm{t}=1.22$ \\
\hline & & & $\mathrm{F}=2.30$ & $\mathrm{~F}=1.64$ & \\
\hline & & 50 & $50.14 \pm 0.90$ & $50.75 \pm 1.45$ & $50.33 \pm 0.92$ \\
\hline & & & $\mathrm{t}=1.32$ & $\mathrm{t}=1.12$ & $\mathrm{t}=1.32$ \\
\hline & & & $\mathrm{F}=2.34$ & $F=1.08$ & \\
\hline & & 100 & $101.98 \pm 0.49$ & $101.15 \pm 1.92$ & $101.35 \pm 0.89$ \\
\hline & & & $\mathrm{t}=1.22$ & $\mathrm{t}=0.32$ & $\mathrm{t}=1.02$ \\
\hline & & & $\mathrm{F}=1.47$ & $F=3.34$ & \\
\hline & & & 285 & 351 & Reference method [23] \\
\hline \multirow[t]{6}{*}{ FASTFIX } & VAR & 10 & $9.93 \pm 0.67$ & $9.98 \pm 1.97$ & $9.963 \pm 0.72$ \\
\hline & & & $t=0.66$ & $t=1.32$ & $t=0.75$ \\
\hline & & & $\mathrm{F}=2.28$ & $\mathrm{~F}=1.04$ & \\
\hline & & 20 & $19.86 \pm 1.17$ & $20.17 \pm 1.03$ & $20.01 \pm 0.40$ \\
\hline & & & $\mathrm{t}=1.32$ & $\mathrm{t}=1.81$ & $\mathrm{t}=0.36$ \\
\hline & & & $\mathrm{F}=1.79$ & $\mathrm{~F}=1.34$ & \\
\hline
\end{tabular}

* Average of five determinations, (four degrees of freedom), At 95\% confidence levelt-value is 2.776 and F-value is 6.26 , **Supplied by NCPI products، Syria, ${ }^{* * *}$ Supplied by UNIPHARMA products, Syria.

\section{DISCUSSION}

In this study, the developed spectrophotometric method is free of organic solvents [16-20, 22, 29], rapid, and has more sensitivity than previous methods $[16-20,22,29,30]$. The proposed method can be carried out without any organic solvents or reagents in contrast with many previous spectrophotometric methods.
All previous reasons make this method easier and cheaper from other spectrophotometric methods.

A comparative summarized study between the proposed methods and previous spectrophotometric methods for determination of SIL and VAR has been provided in table 4 and table 5 respectively.

Table 4: Comparison of the proposed methods with the existing spectrophotometric methods for the determination of Sildenafil citrate

\begin{tabular}{|c|c|c|c|c|c|c|}
\hline Reagent & $\begin{array}{l}\text { Spectrophotometric } \\
\text { Method }\end{array}$ & Solvent & $\begin{array}{l}\text { Temp. } \\
{ }^{\circ} \mathrm{C}\end{array}$ & $\begin{array}{l}\text { Concentration } \\
\text { rang. } \mu \mathrm{g} / \mathrm{ml}\end{array}$ & $\begin{array}{l}\varepsilon \\
\operatorname{lmol} / \mathrm{cm}\end{array}$ & Reference \\
\hline iodine & direct & dichloroethane & $25 \pm 1$ & $15.0-160$ & $3.75 \times 10^{3}$ & [16] \\
\hline TCNQ & direct & acetonitrile & $50 \pm 2$ & $15.0-220$ & $2.58 \times 10^{3}$ & [16] \\
\hline DDQ & direct & methanol & $50 \pm 2$ & $20.0-260$ & $2.41 \times 10^{3}$ & [16] \\
\hline TCNE & direct & acetonitrile & $50 \pm 2$ & $10.0-210$ & $3.05 \times 10^{3}$ & [16] \\
\hline TNF & direct & dichloroethane & $60 \pm 2$ & $15.0-240$ & $2.25 \times 10^{3}$ & [16] \\
\hline chloranilic acid & direct & acetonitrile & $60 \pm 2$ & $20.0-180$ & $3.26 \times 10^{3}$ & [16] \\
\hline chloranil & direct & acetonitrile & $60 \pm 2$ & $28.0-150$ & $3.42 \times 10^{3}$ & [16] \\
\hline bromanil & direct & methanol & $60 \pm 2$ & $15.0-170$ & $2.90 \times 10^{3}$ & [16] \\
\hline
\end{tabular}




\begin{tabular}{|c|c|c|c|c|c|c|}
\hline BCG & extractive & chloroform & $25 \pm 2$ & $1.2-25.0$ & $1.58 \times 10^{4}$ & [17] \\
\hline CCR & extractive & chloroform & $25 \pm 2$ & $1.5-60.0$ & $9.79 \times 10^{3}$ & [17] \\
\hline chromotrope $2 \mathrm{~B}$ & extractive & $\begin{array}{l}\text { Methylene } \\
\text { chloride }\end{array}$ & $25 \pm 2$ & $3.3-87.0$ & $1.02 \times 10^{4}$ & [18] \\
\hline chromotrope $2 \mathrm{R}$ & extractive & $\begin{array}{l}\text { Methylene } \\
\text { chloride }\end{array}$ & $25 \pm 2$ & $3.3-96.0$ & $8.30 \times 10^{3}$ & [18] \\
\hline $\begin{array}{l}\text { 3-phenylazo-6-o-carboxyphenylazo- } \\
\text { chromotropic acid }\end{array}$ & extractive & $\begin{array}{l}\text { Methylene } \\
\text { chloride }\end{array}$ & $25 \pm 2$ & $5.0-115.0$ & $6.83 \times 10^{3}$ & [18] \\
\hline $\begin{array}{l}\text { bis-3,6-(o-hydroxyphenylazo)- } \\
\text { chromotropic acid }\end{array}$ & extractive & $\begin{array}{l}\text { Methylene } \\
\text { chloride }\end{array}$ & $25 \pm 2$ & $2.5-125.0$ & $5.42 \times 10^{3}$ & [18] \\
\hline $\begin{array}{l}\text { bis-3,6-(p-N,N-dimethylphenylazo)- } \\
\text { chromotropic acid }\end{array}$ & extractive & $\begin{array}{l}\text { methylene } \\
\text { chloride }\end{array}$ & $25 \pm 2$ & $8.3-166.7$ & $3.35 \times 10^{3}$ & [18] \\
\hline $\begin{array}{l}\text { 3-phenylazo-6-o-hydroxyphenylazo- } \\
\text { chromotorpic acid }\end{array}$ & extractive & $\begin{array}{l}\text { Methylene } \\
\text { chloride }\end{array}$ & $25 \pm 2$ & $0.8-15.0$ & $2.32 \times 10^{4}$ & [18] \\
\hline BTB & extractive & chloroform & $40 \pm 2$ & $1.0-40.0$ & $20.12 \times 10^{3}$ & [19] \\
\hline PBP & extractive & chloroform & $25 \pm 2$ & $1.0-50$ & $44.40 \times 10^{3}$ & [19] \\
\hline EPPR & extractive & chloroform & $25 \pm 2$ & $3.0-70.0$ & $24.00 \times 10^{3}$ & [19] \\
\hline MCP & extractive & chloroform & $25 \pm 2$ & $3.0-70.0$ & $7.86 \times 10^{3}$ & [20] \\
\hline BCG & direct & dichloromethane & $25 \pm 2$ & $1.3-50.0$ & $2.28 \times 10^{4}$ & [22] \\
\hline BTB & direct & dichloromethane & $25 \pm 2$ & $0.8-27.0$ & $3.05 \times 10^{4}$ & [22] \\
\hline \multicolumn{7}{|l|}{ Proposed method } \\
\hline $\mathrm{KI}+\mathrm{KIO}_{3}(288 \mathrm{~nm})$ & direct & water & $25 \pm 2$ & $0.4-12$ & $6.7659 \times 10^{4}$ & \\
\hline $\mathrm{KI}+\mathrm{KIO}_{3}(351 \mathrm{~nm})$ & direct & water & $25 \pm 2$ & $0.6-16$ & $3.7955 \times 10^{4}$ & \\
\hline
\end{tabular}

Table 5: Comparison of the proposed methods with the existing spectrophotometric methods for the determination of vardenafil hydrochloride

\begin{tabular}{|c|c|c|c|c|c|c|}
\hline Reagent & $\begin{array}{l}\text { Spectrophotometric } \\
\text { method }\end{array}$ & Solvent & $\begin{array}{l}\text { Temp. } \\
{ }^{\circ} \mathrm{C}\end{array}$ & $\begin{array}{l}\text { Concentration rang. } \\
\mu \mathrm{g} / \mathrm{ml}\end{array}$ & $\begin{array}{l}\varepsilon \\
\operatorname{lmol} / \mathrm{cm}\end{array}$ & Reference \\
\hline BCG & extractive & chloroform & $25 \pm 2$ & $5-60$ & $3.755 \times 10^{4}$ & [29] \\
\hline $\begin{array}{l}\text { acetaldehyde+ } \\
\text { sodium nitroprusside }\end{array}$ & direct & $\begin{array}{l}\text { alkaline } \\
\text { medium }\end{array}$ & $25 \pm 2$ & $2-20$ & $4.079 \times 10^{4}$ & [29] \\
\hline $\mathrm{KMnO4}$ & oxidation & $\begin{array}{l}\text { alkaline } \\
\text { medium }\end{array}$ & $25 \pm 2$ & $10-100$ & $4.299 \times 10^{3}$ & [29] \\
\hline $\begin{array}{l}\text { methyl benzothiazolinone } \\
\text { hydrazoneHCL }\end{array}$ & oxidation & $\begin{array}{l}\text { acidic } \\
\text { medium }\end{array}$ & $25 \pm 2$ & $4-40$ & $3.774 \times 10^{4}$ & [30] \\
\hline $\begin{array}{l}\text { 4-aminoantipyrine+potassium } \\
\text { periodate }\end{array}$ & indirect-oxidation & $\begin{array}{l}\text { alkaline } \\
\text { medium }\end{array}$ & $25 \pm 2$ & $4-60$ & $4.605 \times 10^{4}$ & [30] \\
\hline \multicolumn{7}{|l|}{ Proposed method } \\
\hline $\mathrm{KI}+\mathrm{KIO}_{3}(285 \mathrm{~nm})$ & direct & water & $25 \pm 2$ & $0.2-13$ & $6.8719 \times 10^{4}$ & \\
\hline $\mathrm{KI}+\mathrm{KIO}_{3}(351 \mathrm{~nm})$ & direct & water & $25 \pm 2$ & $0.4-40$ & $2.6691 \times 10^{4}$ & \\
\hline
\end{tabular}

We can see this is the unique colorimetric method does not need any organic compound to determine SIL and VAR.

\section{CONCLUSION}

The proposed analytical procedures were simple, rapid, accurate and precise, so it can be used for the routine analysis of SIL and VAR in bulk and pharmaceutical formulations. The sample recoveries from all formulations have good agreement with their respective label claims, which suggested non-interference with formulations excipients in the assay. Moreover, the present method is environment-friendly because it does not need any organic reagents or solvents; it is free extractive and very sensitive comparing with other spectrophotometric methods.

\section{CONFLICT OF INTERESTS}

The authors declare no conflict of interest

\section{REFERENCES}

1. Gareri P, Castagna A, Francomano D, Cerminara G, De Fazio P. Erectile dysfunction in the elderly: an old widespread issue with novel treatment perspectives. Int J Endocrinol 2014. http://dx.doi.org/10.1155/2014/878670

2. Codevilla CF, Castilhos TD, Bergold AM. A review of analytical methods for the determination of four new phosphodiesterase type 5 inhibitors in biological samples and pharmaceutical preparations. Braz J Pharm Sci 2013;49:1-1.

3. Reddy B, Reddy YR. Validation and stability indicating RP-HPLC method for the determination of sildenafil citrate in pharmaceutical formulations and human plasma. J Chem 2008;5 Suppl 2:1117-22.
4. Tripathi AS, Sheikh I, Dewani AP, Shelke PG, Bakal RL, Chandewar AV, et al. Development and validation of RPHPLC method for sildenafil citrate in rat plasmaapplication to pharmacokinetic studies. Saudi Pharm J 2013;21:317-21.

5. Kim J, Ji H, Kim SJ, Lee HW, Lee SS, Kim DS, et al. Simultaneous determination of sildenafil and its active metabolite UK103,320 in human plasma using liquid chromatographytandem mass spectrometry. J Pharm Biomed Anal 2003;32:317-22.

6. Tracqui A, Ludes B. HPLC-MS for the determination of sildenafil citrate (Viagra ${ }^{\circledR}$ ) in biological fluids. Application to the salivary excretion of sildenafil after oral intake. J Anal Toxicol 2003;27:88-94.

7. Aboul-Enein HY, HEFNAWY MM. Rapid determination of sildenafil citrate in pharmaceutical preparations using monolithic silica HPLC column. J Liq Chromatogr Relat Technol 2003;26:2897-908.

8. Berzas JJ, Rodriguez J, Castaneda G, Villaseñor MJ. Voltammetric behavior of sildenafil citrate (Viagra) using square wave and adsorptive stripping square wave techniques: determination in pharmaceutical products. Anal Chim Acta 2000;417:143-8.

9. Özkan SA, Uslu B, Zuman P. Electrochemical oxidation of sildenafil citrate (Viagra) on carbon electrodes. Anal Chim Acta 2004;501:227-33.

10. Berzas Nevado JJ, Villaseñor Llerena MJ, Contento Salcedo AM, Rodríguez Flores J. Development of a capillary gas chromatographic method with flame ionisation detection for the 
simultaneous determination of sildenafil and its N-demethylated metabolite in biological fluids. J Sep Sci 2002;25:767-72.

11. Pelander A, Ojanperä I, Sistonen J, Rasanen I, Vuori E. Screening for basic drugs in 2-ml urine samples by dual-plate over pressured layer chromatography and comparison with gas chromatographymass spectrometry. J Anal Toxicol 2003;27:226-32.

12. Qin W, Li SF. An ionic liquid coating for determination of sildenafil and UK-103,320 in human serum by capillary zone electrophoresis-ion trap mass spectrometry. Electrophoresis 2002;23:4110-6.

13. Flores JR, Nevado JB, Penalvo GC, Diez NM. Development of a micellar electrokinetic capillary chromatography method for the determination of three drugs employed in the erectile dysfunction therapy. J Chromatogr B 2004;811:231-6.

14. Nevado JB, Flores JR, Penalvo GC, Farinas NR. Determination of sildenafil citrate and its main metabolite by sample stacking with polarity switching using micellar electrokinetic chromatography. J Chromatogr A 2002;953:279-86.

15. Nevado JJ, Flores JR, Penalvo GC, Fariñas NR. Micellar electrokinetic capillary chromatography for the determination of Viagra and its metabolite (UK-103,320) in human serum. Electrophoresis 2001;22:2004-9.

16. Amin AS, El-Beshbeshy AM. Utility of certain $\sigma$ and $\pi$-acceptors for the spectrophotometric determination of sildenafil citrate (Viagra). Mikrochim Acta 2001;137:63-9.

17. Dinesh ND, Nagaraja P, Gowda NM, Rangappa KS. Extractive spectrophotometric methods for the assay of sildenafil citrate (Viagra) in pure form and in pharmaceutical formulations. Talanta 2002;57:757-64.

18. Issa YM, El-Hawary WF, Youssef AF, Senosy AR. Spectrophotometric determination of sildenafil citrate in pure form and in pharmaceutical formulation using some chromotropic acid azo dyes. Spectrochim Acta Mol Biomol Spectrosc 2010;75:1297-303.

19. Frag EY, Mohamed GG, Alelaiwi HM. Utility of ion-associate formation reactions for the spectrophotometric determination of sildenafil citrate in pure form and in virecta tablets. Pharm Anal Acta 2011;2:2.

20. Muhamad YH. A simple spectrophotometric assay of sildenafil in pure and pharmaceutical preparations. J Al-Nahrain University 2012;15:18-24.
21. El-Gindy AE, Shokry E, Farouk M, EL-AZIZ L. Validated methods for determination of sildenafil citrate in the presence of its potential impurities. Int J Biomed Res 2010;2:262-78.

22. Sakur AA, Affas S. Direct spectrophotometric determination of sildenafil citrate in pharmaceutical preparations via complex formation with two sulphonphthalein acid dyes. Res J Pharm Tech 2017;10:1191-6.

23. Manisha G, Usha P, Vandana P. Development and validation of RP-HPLC method for estimation of vardenafil in bulk and pharmaceutical formulation. Am J PharmTech Res 2013; 3:928-38.

24. Rao DS, Surendranath KV, Radhakrishnanand P, Suryanarayana MV, Raghuram P. A stability indicating LC method for vardenafil $\mathrm{HCl}$. Chromatographia 2008;68:829-35.

25. Di Y, Zhao M, Nie Y, Wang F, Lv J. A high-performance liquid chromatography: chemiluminescence method for potential determination of vardenafil in dietary supplement. J Anal Methods Chem 2011;20;2011.

26. Idris AM, Alnajjar AO. Multi-response optimization of a capillary electrophoretic method for determination of vardenafil in the bulk drug and in a tablet formulation. Acta Chromatogr 2007;1:19-97.

27. Flores JR, Nevado JB, Penalvo GC, Diez NM. Development of a micellar electrokinetic capillary chromatography method for the determination of three drugs employed in the erectile dysfunction therapy. J Chromatogr B 2004;811:231-6.

28. Gratz SR, Flurer CL, Wolnik KA. Analysis of undeclared synthetic phosphodiesterase-5 inhibitors in dietary supplements and herbal matrices by LC-ESI-MS and LC-UV. J Pharm Biomed Anal 2004;36:525-33.

29. Reddy TV. Spectrophotometric quantification of vardenafil in bulk and tablet. Int J Chem Biol Sci 2015;3:185-92.

30. Kumar AV, Reddy TV, Sekharan C. Spectrophotometric analysis of vardenafil in tablet dosage forms by using electrophilic coupling reagents. Anal Bioanal Chem 2016;3:29-39.

31. Khateeb M, Elias B, Al Rahal F. Validated spectrophotometric method to assay of B6 and B3 vitamins in pharmaceutical forms using potassium iodide and potassium iodate. Int Lett Chem Physics Astronomy 2015;60:113-9. 